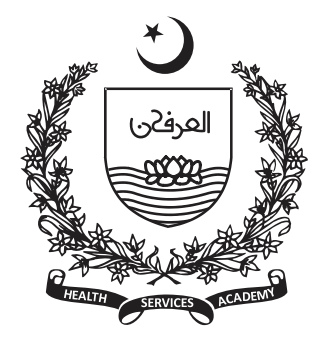

${ }^{1}$ Assistant professor, Department of Community Medicine, Azad Jammu and Kashmir Medical College, Muzaffarabad 2 Assistant professor, Department of Community Medicine, AFPGMI Rawalpindi, National University of Medical sciences (NUMS)

${ }^{3}$ Fellow Surgical Oncology, Shaukat Khanum Memorial Hospital Lahore

4 Resident Histopathology, PIMS, Islamabad

${ }^{5}$ Vice Chancellor, Health

Services Academy, Islamabad

Corresponding Author:

Sara Bashir Kant

Email:

drsaranisar@gmail.com

\section{Determinants of Exclusive Breastfeeding among Mothers in Rawalpindi: A Cross Sectional Study}

\author{
Sara Bashir Kant ${ }^{1}$, Humaira Mahmood ${ }^{2}$, Masood ur Rehman³, \\ Misha Anis ${ }^{4}$, Assad Hafeez ${ }^{5}$
}

\begin{abstract}
Background: Exclusive Breast Feeding is one of the most cost effective and simple ways to ensure child health and survival and is the single most instrumental intervention that leads to decreased child mortality and morbidity. This study was done to determine the frequency of exclusive breast feeding among mothers in rural Rawalpindi and to determine the frequency of factors affecting exclusive breast feeding among mothers in rural Rawalpindi.
\end{abstract}

Methods: It was a descriptive cross- sectional study, conducted in 6 months in Union Council Mandra, from November 2014 to April 2015. A sample size of 245 was selected through non-probability consecutive sampling. Data was collected on a structured questionnaire from mothers visiting the RHC Mandra facility after taking informed consent. Data was analyzed in the statistical software SPSS 10.

Results: The frequency of Exclusive Breast Feeding (EBF) determined in the study was $52.2 \%$. 29\% mothers had primary level education, $52.7 \%$ had deliveries in the public hospitals and $46.5 \%$ were house wives. The birth order, age of the child, number of antenatal visits, birth wt. and mode of delivery $(p<0.05)$ were significantly associated with EBF. The association of mother's and father's education level, monthly income, birth interval and mother's occupation with EBF were not statistically significant ( $p>0.05)$.

Conclusion: Health education by health professionals during antenatal period to initiate and maintain exclusive breast feeding should be strengthened by focusing more on the nutritional aspects of the newborn babies and its benefits in the later life.

Keywords: Exclusive breast feeding; determinants; child health

\section{Introduction}

$\mathrm{E}$ xclusive Breast Feeding is one of the most simple and cost effective way to ensure healthy child survival.(1)and is the single most instrumental intervention that leads to decreased child mortality and morbidity.(2) The World Health Organization recommends exclusive breast feeding for up to 6 months of life that is followed by complementary foods for up to two years of age.(3,4)Every year about 800,000 child lives can be saved if breast feeding is started within an hour of 
birth and is continued up to two years of life. Globally, less than $40 \%$ of infants under six months of age are exclusively breastfed.(5)Exclusive breastfeeding has been proved as an essential practice to ensure child health and development and is also beneficial for mother's health.(6)Data from developing countries shows that the prevalence of EBF has increased from $33 \%$ in 1995 to $39 \%$ in 2010. The prevalence of EBF has increased in almost all regions in the developing world, and a major improvement was seen in West and Central Africa where the prevalence has been doubled from $12 \%$ to $28 \%$, while less improvements were observed in South Asia where the increase was from $40 \%$ in 1995 to $45 \%$ in 2010(7). It has been reported from Eastern Mediterranean Regional Office (EMRO) of WHO that there is greater than $60 \%$ rate of early breast feeding initiation with almost $60 \%$ of mothers continuing breast feeding up to twelve months but rate of Exclusive Breast Feeding for under six months of infants is only $40 \%$ or less.(8) It is seen that there is lack of exclusive breast feeding as well as other unsafe practices like pre lacteal feeds and discarding colostrum, in Pakistan.(9) Exclusive breast feeding for the first 6 months of life remains essential, and provides critical protection to infants from infections in the environments lacking safe water supply and sanitation.(10)Proportion of children under age 6 months who are exclusively breast fed was 38\% according to PDHS 2006-07, has remained unchanged in the past 6 years and is still $38 \%$. IYCF strategy 2008 aimed to increase the prevalence of EBF to $55 \%$ but this couldn't be achieved.(11)This study was done to determine the frequency of exclusive breast feeding among mothers in rural Rawalpindi and to determine the frequency of factors affecting exclusive breast feeding among mothers in rural Rawalpindi.

\section{Methodology}

It was a descriptive Cross- sectional study, conducted in Union Council Mandra, outskirts of Rawalpindi. RHC Mandra is a rural health center situated in the rural area of District Rawalpindi. It was completed in 6 months duration, from November 2014 to April 2015. A Sample of 245 breast feeding mothers was calculated using WHO's statistical sample size calculator with desired confidence interval of $95 \%$, prevalence of $6 \%(5)$ of women who delivered by c-section in study from Ghana and absolute precision taken was $3 \%$. Sampling technique used was NonProbability Consecutive Sampling. All mothers having children under 2 years of age visiting the RHC facility were selected. Mothers who were suffering from chronic diseases that are barrier to breast feeding, and mothers of children with congenital anomalies which prevent breast feeding e.g. Clift-lip and cleft-palate were excluded from the study. Before starting the study, permission from ethical committee of Health Services Academy, Islamabad was taken. Data were collected through pre tested questionnaire, developed after extensive literature search, in Urdu language and validated by a Pediatrician and a Gynecologist. After taking informed consent of mothers, data was collected from the mothers by the principal researcher through interview. The questionnaire included socio demographic, antenatal and natal variables. Data were analyzed in the statistical software SPSS 10. Qualitative variables as gender of baby, mother's education, mode of delivery, place of delivery, birth order and antenatal visits were measured as frequencies and percentages. For quantitative variables as age of mother, age of baby, birth interval and number of antenatal visits, mean and standard deviation were calculated. Effect modifiers like age of mother, age of baby, birth order, birth interval, education, monthly income, occupation and whether living in joint family, were controlled by stratification. Post stratification chi-square test was applied. Level of significance taken was $\mathrm{p} \leq 0.05$.

\section{Results}

The frequency of Exclusive Breast Feeding among the study participants was 128 out of 245 ( $52.2 \%)$.Table no:1 shows the socio-demographic characteristics of the mothers. $36(14.7 \%)$ mothers were uneducated and 71 mothers i.e. 29\%, had primary education. 167 $(68.2 \%)$ females had undergone normal vaginal deliveries and $78(31.8 \%)$ had delivered babies by csection.167 mothers (68.2\%) were having monthly income between Rs. 5000 to Rs. 20,000 per month. 9 (3.7\%) mothers had monthly income less than Rs. 5000 and $69(28.2 \%)$ had monthly income above Rs. 20,000. 198 children $(81 \%)$ had birth weight between 2.5 to $3.5 \mathrm{Kg}$. 
Table 1. Socio demographic characteristics of the respondents $(n=245)$

\begin{tabular}{|c|c|c|c|}
\hline \multicolumn{2}{|l|}{ Variable } & $\begin{array}{l}\text { Frequency } \\
\text { (n) }\end{array}$ & $\begin{array}{c}\text { Percentage } \\
\%\end{array}$ \\
\hline \multicolumn{2}{|c|}{ Exclusive breast feeding } & 128 & 52.2 \\
\hline \multirow{5}{*}{$\begin{array}{l}\text { Mother's } \\
\text { education }\end{array}$} & Uneducated & 36 & 14.7 \\
\hline & Primary & 71 & 29.0 \\
\hline & Middle & 43 & 17.6 \\
\hline & Matric & 61 & 24.9 \\
\hline & others & 34 & 13.9 \\
\hline \multirow{2}{*}{$\begin{array}{l}\text { Antenatal } \\
\text { checkups }\end{array}$} & Yes & 230 & 93.9 \\
\hline & No & 15 & 6.1 \\
\hline \multirow[t]{2}{*}{$\begin{array}{l}\text { Mode of } \\
\text { delivery }\end{array}$} & $\begin{array}{l}\text { Normal } \\
\text { delivery }\end{array}$ & 167 & 68.2 \\
\hline & c-section & 78 & 31.8 \\
\hline \multirow[t]{3}{*}{$\begin{array}{l}\text { Place of } \\
\text { delivery }\end{array}$} & $\begin{array}{l}\text { Public } \\
\text { hospital }\end{array}$ & 129 & 52.7 \\
\hline & Home & 30 & 12.2 \\
\hline & $\begin{array}{l}\text { Private } \\
\text { clinic }\end{array}$ & 86 & 35.1 \\
\hline \multirow[t]{2}{*}{ Child sex } & Male & 124 & 50.6 \\
\hline & Female & 121 & 49.4 \\
\hline \multirow{4}{*}{$\begin{array}{l}\text { Birth } \\
\text { order }\end{array}$} & First & 80 & 32.7 \\
\hline & Second & 82 & 33.5 \\
\hline & Third & 49 & 20 \\
\hline & $\begin{array}{l}\text { More than } \\
\text { three }\end{array}$ & 34 & 13.9 \\
\hline
\end{tabular}

Age of mother and child, number of antenatal visits and birth interval are shown in table no:2 with their mean and standard deviations:

Table 2. Mean and Standard deviation of quantitative variables $(\mathrm{n}=\mathbf{2 4 5})$

\begin{tabular}{|l|l|l|l|}
\hline Variable & $\begin{array}{l}\text { Frequency } \\
(\mathrm{n})\end{array}$ & Mean & $\begin{array}{l}\text { Standard } \\
\text { deviation }\end{array}$ \\
\hline $\begin{array}{l}\text { Age of } \\
\text { mother }\end{array}$ & 245 & $\begin{array}{l}26.68 \\
\text { years }\end{array}$ & $\begin{array}{l}4.92518 \\
\text { years }\end{array}$ \\
\hline Age of child & 245 & $\begin{array}{l}10.76 \\
\text { months }\end{array}$ & $\begin{array}{l}6.29542 \\
\text { months }\end{array}$ \\
\hline $\begin{array}{l}\text { Birth } \\
\text { interval }\end{array}$ & 245 & $\begin{array}{l}20.06 \\
\text { months }\end{array}$ & $\begin{array}{l}19.573 \\
\text { months }\end{array}$ \\
\hline $\begin{array}{l}\text { Antenatal } \\
\text { visits }\end{array}$ & 245 & $\begin{array}{l}3.8571 \\
\text { times }\end{array}$ & $\begin{array}{l}1.4315 \\
\text { times }\end{array}$ \\
\hline
\end{tabular}

Association of EBF with age of mother $(p=0.506)$, mother's education $(p=0.213)$, father's education $(\mathrm{p}=0.415)$, child gender $(\mathrm{p}=0.956)$ was not statistically significant. Statistically significant results are shown in table no:3 with variables and their respective p-values:

Table 3. Statistically significant variables and their p-values

\begin{tabular}{|c|c|c|c|c|}
\hline \multirow[t]{2}{*}{ Variable } & \multirow[t]{2}{*}{ Categories } & \multicolumn{2}{|c|}{$\begin{array}{l}\text { Exclusive } \\
\text { breast feeding }\end{array}$} & \multirow{2}{*}{$\begin{array}{l}\text { Chi- } \\
\text { square test } \\
\text { p- value } \\
(p \leq 0.05)\end{array}$} \\
\hline & & Yes & No & \\
\hline \multirow{4}{*}{$\begin{array}{l}\text { Age of } \\
\text { child }\end{array}$} & 0-6 months & 44 & 27 & \multirow{4}{*}{0.02} \\
\hline & 7 -12 months & 45 & 54 & \\
\hline & 13-18 months & 36 & 26 & \\
\hline & 19-24 months & 3 & 10 & \\
\hline \multirow{4}{*}{$\begin{array}{l}\text { Birth } \\
\text { order }\end{array}$} & First & 50 & 30 & \multirow{4}{*}{0.043} \\
\hline & Second & 34 & 48 & \\
\hline & Third & 24 & 25 & \\
\hline & $\begin{array}{l}\text { more than } \\
\text { three }\end{array}$ & 20 & 14 & \\
\hline \multirow{4}{*}{$\begin{array}{l}\text { Birth } \\
\text { weight }\end{array}$} & Don't know & 9 & 19 & \multirow{4}{*}{0.04} \\
\hline & $\begin{array}{l}\text { less than } 2.5 \\
\mathrm{~kg}\end{array}$ & 2 & 3 & \\
\hline & $2.5-3.5 \mathrm{~kg}$ & 113 & 87 & \\
\hline & $\begin{array}{l}\text { More than } \\
3.5 \mathrm{~kg}\end{array}$ & 4 & 8 & \\
\hline \multirow{6}{*}{$\begin{array}{l}\text { No.of } \\
\text { antenatal } \\
\text { visits }\end{array}$} & Zero & 9 & 6 & \multirow{6}{*}{0.001} \\
\hline & One & 1 & 2 & \\
\hline & Two & 6 & 12 & \\
\hline & Three & 21 & 35 & \\
\hline & Four & 26 & 33 & \\
\hline & $\begin{array}{l}\text { More than } \\
\text { four }\end{array}$ & 65 & 29 & \\
\hline \multirow{2}{*}{$\begin{array}{l}\text { Mode } \\
\text { of } \\
\text { delivery }\end{array}$} & $\begin{array}{l}\text { Normal } \\
\text { delivery }\end{array}$ & 95 & 72 & \multirow{2}{*}{0.03} \\
\hline & C-section & 33 & 45 & \\
\hline
\end{tabular}

Association of EBF with age of baby showed statistically significant result with $p=0.02$. The relationship between birth order and EBF was statistically significant i.e. $p=0.04$. Association of EBF with mode of delivery and number of antenatal checkups show statistically significant result with $p=0.03$ and $p=0.001$ respectively. The women who had normal deliveries showed increase frequency of EBF. $p=0.04$ shows statistically significant association of birth weight with frequency of EBF.

\section{Discussion}

Breast feeding is a universal phenomenon and is common in almost all cultures of the world. There is universal awareness of the benefits of breast feeding 
for both mother and the baby.(12)Pakistan is one of the signatories of International Code on Marketing of Breast milk substitutes but unfortunately, the prevalence of exclusive breast feeding in Pakistan remains the same since the last decade i.e. $38 \% .{ }^{(10)}$ The frequency of exclusive breast feeding found in this study was $52.2 \%$. This was higher as compared to $33 \%$ and $40 \%$ determined from studies in Islamabad and Karachi. $(13,14)$ This might be because of difference in the socio demographic characteristics of the study participants. In this study, there were $50.6 \%$ male children and $49.4 \%$ female children. These findings are to extent similar with the findings from study in rural area of Bangladesh where there were $48.8 \%$ female and $51.2 \%$ male children. (15) There was nonsignificant association of gender of baby and exclusive breast feeding. This is in contrast to the findings from study in Nigeria which showed female babies were more likely to be breast fed than male babies. (16) The frequency of mother's education showed that $14.7 \%$ mothers had no education and most of the mothers i.e.29\% had primary level education. These findings are consistent with the findings from PDHS 2012-13 which also shows higher percent of primary education in women of rural areas of Punjab. (17) In a community based cross sectional survey in North West Ethiopia, there was significant association of mother's education with frequency of exclusive breast feeding. (18) But in this study, statistically nonsignificant result with $p=0.213$ was observed. This was supported by finding from study done in Iran.(19) Normal deliveries were significantly associated with the increase in frequency of exclusive breast feeding $(p=0.012)$. This significant association of mode of delivery and EBF was also seen in study by Joshi PC et al in Bangladesh in 2014 and as well as in study done in Lebanon in 2013. (20,15)The relationship between birth order and EBF was statistically significant i.e. $p=0.046$. This finding is consistent with results of study in Sri Lanka(15)Mean age of children in the study was 10.76 months with SD \pm 6.295 . There was statistically significant association of EBF with age of $\operatorname{child}(\mathrm{p}=0.02)$. This significant association was also seen in studies done in Ethiopia, Nigeria and Kenya. $(21,22,16,23) 93.9 \%$ participants had antenatal checkups in this study. Mean number of antenatal visits was 3.85 visits. The p-value obtained for the association of number of antenatal visits and EBF was $p=0.001$. In Cochrane data base systematic review, it is suggested that antenatal education of breast feeding increases breast feeding duration.(24)

\section{Conclusion}

Health education by health professionals during antenatal period to initiate and maintain exclusive breast feeding should be strengthened by focusing more on the nutritional aspects of the newborn babies and its benefits in the later life

\section{Recommendations}

Health education by health professionals during antenatal period to initiate and maintain exclusive breast feeding should be strengthened by focusing more on the nutritional aspects of the newborn babies and its benefits in the later life. Government health services should emphasize on regular trainings of the staff on breast feeding especially the staff working in maternity wards and antenatal clinics so that they can help in timely initiation of breast feeding of mothers and also to help mothers if they are having problems regarding initiation as well as maintenance of breast feeding. Mothers should be encouraged by community health workers at their homes to practice exclusive breast feeding up to six months and to continue breast feeding along with complementary foods up to two years.

\section{References}

1. Mgongo M, Mosha M, Uriyo J, Msuya S, Stay-Pederson B. Prevalence and predictors of exclusive breastfeeding among women in Kilimanjaro region, Northern Tanzania: a population based cross-sectional study.International Breastfeeding Journal.2013; 8:12.

2. Hanif H. Trends in breastfeeding and complementary feeding practices in Pakistan. International Breastfeeding Journal.2011; 6:15.

3. World Health Organization: Exclusive breastfeeding for six months best for babies everywhere[internet]. 2011[cited 2014 March 10]. Available from: http://www.who.int/mediacentre/news/statements/2 011/breastfeeding_20110115/en/index.html.

4. Ahmed M, Sughra U, Kalsum U, Imran M, Hadi U. Effect of antenatal counseling on Exclusive Breast Feeding. J Ayub Med CollAbottabad. Apr-Jun 2012;24:1169.

5. World Health Organization: 10 facts on breastfeeding [internet]. 2014 [updated 2014 Feb; cited 2014 March 13]. Available from http://www.who.int/features/factfiles/breastfeeding/ en/. 


\section{Determinants of Exclusive Breastfeeding among Mothers in Rawalpindi: A Cross Sectional Study}

6. Tampah-Naah A,Kumi- Kyereme A. Determinants of exclusive breastfeeding among mothers in Ghana:a cross sectional study. International Breastfeeding Journal. 2013;8:13.

7. Haroon S, Das JK, Salam RA, Imdad A, Bhutta ZA. Breastfeeding promotion interventions and breastfeeding practices: a systematic review. BMC Public Health. 2013;13(Suppl 3):S20. .

8. World Health organization. Regional Officefor the Eastern Mediterranean (EMRO): Breastfeeding [Internet]. 2014 [cited 2014 April 12]. Available from.

9. Ali S, Ali S, Imam A, Ayub S, Billoo A. Perception and practices of breastfeeding of infants 0-6 months in an urban and semi urban community in Pakistan: a crosssectional study. JPMA. 2011 Jan; 61:99-104.

10. United Nations Children's Fund. Situation Analysis of Children and women in Pakistan. National report. The living environment for children and women :Health. June 2012; 54.

11. Pakistan Demographic and Health Survey 2012-13. Nutrition of children and women.11; 170-2.

12. Hanif R, Khalil E, Sheikh A, Harji A, Haris S, Rasheed $\mathrm{MW}$, et al. Knowledge about breastfeeding in accordance with the national policy among doctors, paramedics and mothers in baby-friendly hospitals. JPMA. 2010; 60:881.

13. Joshi PC, Angdembe MR, Das SK, Ahmed S, Faruque ASG, Ahmed T. Prevalence of exclusive breastfeeding and associated factors among mothers in rural Bangladesh: a cross-sectional study. International Breastfeeding Journal 2014;9:7.

14. Hanif S, Murtaza G, HanifMemon M. Factors Associated with Cessation of Breast Feeding. Journal of the Dow University ofHealth Sciences Karachi 2011;5(1): 2125.

15. Perera PJ, Ranathunga N, Fernando MP, Sampath W, Samaranayake GB. Actual exclusive breastfeeding rates and determinants among a cohort of children living in Gampaha district Sri Lanka: A prospective observational study.International Breastfeeding Journal. 2012;7:21.

16. Setegn T, Belachew T, Gerbaba M, Deribe K, Deribew A, Biadgilign S. Factors associated with exclusive breastfeeding practices among mothers in Goba district, south east Ethiopia: a cross-sectional study. International Breastfeeding Journal. 2012;7:17

17. Pakistan Demographic and Health survey201213. Characteristics of respondents.3;39.

18. Alade O, Titiloye MA, Oshiname FO, Arulogun OS. Exclusive breastfeeding and related antecedent factors among lactating mothers in a rural community in Southwest Nigeria. Int J Nurs Midwifery. 2013 5(7):132-8.

19. Roostaee F, Tabatabaei SM, Zaboli M, et al. Breastfeeding Continuation in South-Eastern of Iran: the Associated Factors. Medical Archives. 2015;69(2):98-102.

20. Dashti M, Scott JA, Edwards CA, Al-Sughayer M. Determinants of breastfeeding initiation among mothers in Kuwait. International Breastfeeding Journal 2010;5:7.

21. Kimani-Murage EW, Madise NJ, Fotso J-C, Kyobutungi C, Mutua MK, Gitau TM, et al. Patterns and determinants of breastfeeding and complementary feeding practices in urban informal settlements, Nairobi Kenya BMC Public Health 2011, 11:396.

22. Setegn T, Gerbaba M, Belachew T. Determinants of timely initiation of breastfeeding among mothers in Goba Woreda, South East Ethiopia: A cross sectional study. BMC Public Health 2011, 11:217.

23. Sefene A, Birhanu D, Awoke W, Taye T. Determinants of Exclusive Breastfeeding Practice among Mothers of Children Age Less Than 6 Month in Bahir Dar City Administration, Northwest Ethiopia; A Community Based Cross-Sectional Survey. Science Journal of Clinical Medicine 2013;2(6):153-9.

24. Lumbiganon $P$, Martis R, Laopaiboon M, Festin MR, Ho JJ, Hakimi M. Antenatal breastfeeding education for increasing breastfeeding duration. The Cochrane database of systematic reviews. 2011;(11):CD006425. 